\title{
PENGARUH KINERJA KEUANGAN BANK TERHADAP RATING OBLIGASI BANK DI INDONESIA
}

\author{
Theofilus Steven Susanto \\ Bertha Silvia Sutejo (bertha7381@yahoo.com) \\ Deddy Marciano \\ Fakultas Bisnis dan Ekonomika Universitas Surabaya
}

\begin{abstract}
This research was conducted to provide empirical evidence about the effect of bank's financial performance using CAMEL ratios (CAR, NPL, BMPK, BOPO, LDR), and SIZE as control variable toward bank's bond rating in Indonesia from 2005 to 2009. The source of research data are financial reports obtained from Direktori Perbankan Indonesia and the source of bond rating data are obtained from official website of Pefindo. In data processing, researcher used ordered probit method analyzed using Eviews 4. From the research, it appeared that the capital adequacy and the size have positive effect toward bond rating. Asset quality, earnings, and liquidity have negative effect toward bond rating. There is no significant effect between management quality and bond rating. It can be concluded that the bond rating of banks in Indonesia from 2005 to 2009 influenced by capital adequacy, asset quality, earnings, liquidity, and size.
\end{abstract}

Keywords: financial performance, bond rating, ordered probit, CAMEL

\section{LATAR BELAKANG}

Setiap badan usaha membutuhkan sumber daya untuk memenuhi kebutuhan, terutama dalam hal keuangan. Sumber pendanaan dapat berasal dari internal maupun eksternal. Untuk pendanaan jangka pendek, biasanya mengunakan utang jangka pendek atau utang lancar. Sedangkan pendanaan jangka panjang salah satu contohnya adalah obligasi. Sumber pendanaan tersebut di Indonesia saat ini menjadi atraktif dan diprediksikan semakin atraktif pada tahun 2012. Hal ini karena makro perekonomian Indonesia semakin solid serta ditunjang dengan kenaikan peringkat utang Indonesia ke kategori layak investasi (investment grade) oleh Fitch Ratings pada 15 Desember 2011 dan Moody's Investors Services 18 Januari 2012.

Terdapat 2 hal yang perlu diperhatikan investor sebelum mengambil keputusan berinvestasi, yaitu risiko kredit dan asimetric information. Risiko kredit terjadi jika counterparty (pihak lain dalam transaksi bisnis kita) tidak bisa memenuhi kewajibannya (wanprestasi). Risiko kredit menjadi semakin penting karena akhir-akhir ini banyak peristiwa gagal bayar yang dialami oleh perusahaan-perusahaan domestik, luar negeri, bahkan negara sekalipun. Sebagai contoh, pada tahun 1980-an, pinjaman yang diberikan kepada negara berkembang (seperti negara Amerika Latin) mengalami masalah sehingga mendorong bank-bank yang member pinjaman mengalami kesulitan. Pada saat krisis ekonomi yang melambat, persoalan risiko kredit semakin menjadi lebih serius (Mamduh, 2009).

Faktor kedua yang perlu diperhatikan investor adalah adalah asimetri informasi. Penman (2001) dalam Michell (2008) mengatakan bahwa penggunaan informasi yang diberikan oleh perusahaan oleh masing-masing pihak sangat terkait dengan adanya asimetri informasi yang terjadi antara pihak manajemen dan pihan eksternal (terutama kreditor dan investor). Penyebab munculnya asimetri informasi ini disampaikan oleh Richardson (1998) dalam Silvia (2011) yang meneliti hubungan antara asimetri informasi (yang diukur dari bid-ask spread dan dispersi analysts' forecast) dan earnings management. Berdasarkan hasil penelitiannya, 
ia menyimpulkan bahwa terdapat hubungan positif signifikan antara asimetri informasi dan eanings management. Burgstahler \& Dichev (1997) dalam Silvia (2011) menemukan bahwa perusahaan melakukan earnings management untuk menghindari melaporkan kerugian atau penurunan laba. Hasil penelitian ini lebih konsisten dengan OEM (Opportunistic Earning Management). Begitu pula penelitian yang dilakukan oleh Kasanen, Kinnunen \& Niskanen (1996), seperti yang dijelaskan dalam Bernard \& Skinner (1996) dalam Silvia (2011), menemukan bahwa perusahaan-perusahaan di Finlandia melakukan earnings management untuk memenuhi permintaan dividen oleh investor institusi, dimana hasil ini lebih konsisten dengan penjelasan OEM.

Untuk mengantisipasi risiko kredit dan asimetri informasi tersebut, ada beberapa cara yang dapat dilakukan oleh calon investor, salah satunya dengan mengamati rating obligasi dari suatu perusahaan. Perusahaan yang menerbitkan surat utang biasanya akan di-rating oleh lembaga pe-rating. Rating tersebut menunjukkan tingkat risiko perusahaan tersebut. Melalui rating tersebut, calon pembeli obligasi diharapkan memperoleh gambaran mengenai risiko perusahaan yang akan menerbitkan surat utang tersebut (Mamduh, 2009).

Di Indonesia, Pefindo merupakan salah satu contoh dari lembaga pe-rating obligasi. Penentuan rating tersebut dilakukan dengan mengamati beberapa hal yang relevan dengan kemampuan membayar utang badan usaha. Penilaian risiko industri pada sektor lembaga keuangan meliputi beberapa point penting, yaitu: (1) Pertumbuhan industri dan stabilitas (growth and stability), (2) Struktur pendapatan \& struktur biaya dari Industri (revenue and cost structures), (3) Persaingan didalam industri (competition within the industry), (4) Peraturan (regulatory framework), dan (5) Profil Keuangan (financial profile).

Dari penilaian tersebut, dapat dikatakan bahwa kondisi kinerja keuangan suatu lembaga kevangan merupakan hal yang penting dan berpengaruh pada rating obligasi lembaga tersebut. Kondisi kinerja keuangan yang semakin baik akan membantu lembaga keuangan untuk memperoleh rating obligasi yang lebih baik pula. Hal inilah yang menjadi kesimpulan dari Michell (2008) yang mengatakan bahwa ada pengaruh kinerja keuangan yang dinilai dengan menggunakan rasio-rasio keuangan terhadap pemeringkatan obligasi.

Untuk menilai kinerja keuangan suatu lembaga keuangan, khususnya bank, ada beberapa metode yang dapat digunakan, salah satunya adalah metode CAMEL. Bank Indonesia menggunakan CAMEL sebagai tolok ukur penilaian kinerja bank yang didasarkan pada lima aspek, yaitu modal (capital), aktiva (asset), manajemen (management), pendapatan (earning), dan likuiditas (liquidity). Kelima aspek ini saling terkait dan tidak semuanya harus diperhatikan untuk menciptakan suatu bank yang sehat. James B. Thomson (1991) juga mengatakan bahwa metode CAMEL berpengaruh secara signifikan terhadap probabilitas kebangkrutan. Probabilitas kebangkrutan bank adalah sebuah fungsi dari variabel-variabel yang berhubungan dengan solvency, termasuk rasio capital adequacy, asset quality, management quality, earning performance, dan liquidity.

Berdasarkan hal tersebut, maka permasalahan utama dari penelitian ini adalah apakah ada pengaruh kinerja keuangan terhadap rating obligasi bank di Indonesia periode 2005-2009? . Dalam hal tersebut, peneliti kemudian menguji lebih dalam terkait apakah CAR mempengaruhi rating obligasi bank secara positif? Apakah NPL mempengaruhi rating obligasi bank secara negatif? Apakah BOPO mempengaruhi rating obligasi bank secara negatif? Dan apakah LDR mempengaruhi rating obligasi bank secara negatif?

\section{LITERATUR REVIEW DAN PENGEMBANGAN HIPOTESIS}

\section{Fungsi Intermediasi Bank}

Menurut Susilo, dkk (2000; p.6) secara umum fungsi utama bank adalah menghimpun dana dari masyarakat dan menyalurkan kembali kepada masyarakat untuk berbagai tujuan atau 
sebagai financial intermediary. Secara lebih spesifik fungsi bank (1) agent of trust, (2) agent of development, (3) agent of service. Hal ini didukung oleh pendapat dari Taswan (2006; p.6) yang mengatakan bahwa bank adalah suatu lembaga yang berperan sebagai lembaga perantara keuangan (financial intermediary) antara pihak-pihak yang membutuhkan dana (deficit spending unit), serta berfungsi untuk memperlancar lalu lintas pembayaran giral. Jadi dapat dikatakan bahwa bank berfungsi sebagai lembaga intermediasi yang dapat menggerakkan sektor riil. Oleh karena itu, kinerja bank haruslah baik agar sektor riil dapat tumbuh dengan baik pula.

\section{Risiko Perbankan}

Menurut Siamat (1999; p.91) risiko usaha atau business risk bank merupakan tingkat ketidakpastian mengenai pendapatan yang diperkirakan akan diterima. Secara tradisional, risiko diukur dengan deviasi standar atau koefisien variasi dari return. Penilaian risiko diawali dengan mengidentifikasikan risiko yang bertujuan agar dapat mengetahui jenis risiko yang ada pada tiap aktivitas fungsional yang nantinya dapat merugikan bank. Menurut Taswan (2006; p.298) ada 4 macam risiko yang wajib diperhatikan oleh tiap bank, yaitu: risiko kredit, risiko likuiditas, risiko pasar, dan risiko operasional.

\section{Kebangkrutan Bank}

Menurut Akyar dan Eha (2000; p.137) dalam Spica dan Winny (2005; p.4) kebangkrutan adalah suatu keadaan dimana perusahaan tidak mampu memenuhi kewajibannya dikarenakan memiliki kekurangan dana sehingga tidak dapat menjalankan kegiatan usahanya. Hubbard (2005; p.281) menyatakan "Like other firms, bank can become financially distressed and fail. A bank fail occurs when a bank cannot pay its depositors in full with enough reserves left to meet its reserve requirement." Jadi bank seperti perusahaan lainnya juga dapat mengalami tekanan keuangan dan kegagalan. Menurut Arena (2005) ada beberapa macam bank yang masuk dalam kategori bank yang mengalami kegagalan, yaitu:

1. The financial institution was recapitalized by either the central bank or the agency specifically created to address the crisis, and/or required a liquidity injection from the monetary authority;

2. The financial institution's operations were temporarily suspended (frozen) by a government;

3. The government closed the financial institution;

4. The financial institution was absorbed or acquired by another financial institution.

Hal ini diperkuat oleh pendapat dari Hadad, dkk (2004) yang mengatakan bahwa bank berstatus pailit, apabila bank tersebut berada pada situasi legal bankruptcy, di mana bank dinyatakan pailit secara sah menurut undang-undang kepailitan. Adapun bank bankrut meliputi bank berstatus bank likuidasi (BDL), bank stop operasi (BSO), bank take over (BTO), bank beku kegiatan usaha (BBKU) dan bank rekap.

\section{Obligasi}

Menurut Eduardus (2010; p.40), obligasi (bond) dikeluarkan penerbitnya sebagai surat tanda bukti hutang. Obligasi adalah sekuritas yang memuat janji untuk memberikan pembayaran tetap menurut jadwal yang telah ditetapkan. Obligasi itu sendiri merupakan sertifikat atau surat berharga yang berisi kontrak antara investor sebagai pemberi dana dengan penerbitnya sebagai peminjam dana. Penerbit obligasi mempunyai kewajiban kepada pemegangnya untuk membayar bunga secara reguler sesuai jadwal yang telah ditetapkan serta melunasi kembali pokok pinjaman pada saat jatuh tempo. Sebutan obligasi semakin dikenal dengan istilah sekuritas pendapatan tetap (fixed income securities). Obligasi dapat dibedakan menurut siapa penerbitnya, yaitu obligasi negara dan obligasi perusahaan. Terdapat tiga karakteristik yaitu nilai nominal, kupon, dan jatuh tempo. 
Faktor penting bagi investor sebelum berinvestasi di obligasi adalah mengenal penerbit dan seluk-beluk obligasi yang diterbitkannya. Hal itu perlu dilakukan untuk menaksir besarnya risiko khususnya risiko gagal bayar (default) yang mungkin dapat dialami investor di masa mendatang. Mamduh (2009; p. 169) berkata bahwa perusahaan atau bahkan negara seperti Indonesia, yang akan menerbitkan surat hutang, baik jangka panjang (obligasi) atau pendek (commercial paper), biasanya akan di-rating oleh perusahaan pe-rating. Rating tersebut menunjukkan tingkat risiko perusahaan tersebut. Salah satu contoh lembaga perating obligasi di Indonesia adalah PT PEFINDO. Peringkat obligasi yang ditetapkan adalah dari AAA (sangat istimewa atau superior) sampai dengan D (gagal bayar).

\section{Kinerja keuangan bank}

Rasio keuangan dapat menjadi indikator keuangan untuk mengungkapkan kondisi keuangan maupun performance yang telah dicapai oleh bank tersebut dalam suatu periode tertentu. Menurut Martono (2004; p.88), metode yang dapat digunakan sebagai dasar penilaian adalah CAMEL, yang meliputi 5 aspek, yaitu Capital adequacy, Assets quality, Management quality, Earnings, Liquidity.

\section{Capital Adequacy}

Adalah kemampuan bank dalam mempertahankan modal yang mencukupi dan kemampuan manajemen dalam mengidentifikasi, mengukur, mengawasi, dan mengontrol risiko-risiko yang timbul yang dapat berpengaruh terhadap besarnya modal bank. Rasio yang digunakan untuk mengukur capital adequacy adalah CAR (Capital Adequacy Ratio). CAR adalah rasio yang memperlihatkan seberapa besar jumlah seluruh aset bank yang mengandung risiko (kredit, penyertaan, surat berharga, tagihan pada bank lain) ikut dibiayai dari modal sendiri disamping memperoleh dana-dana dari sumber di luar bank, yaitu dengan cara membandingkan modal terhadap aset tertimbang menurut risiko (ATMR). Sejalan dengan standar yang telah ditetapkan oleh Bank of International Settlements (BIS), terhadap seluruh bank di Indonesia diwajibkan untuk menyediakan modal minimum sebesar $8 \%$ dari ATMR.

\section{Assets quality}

Menunjukkan kualitas asset sehubungan dengan risiko kredit yang dihadapi bank akibat pemberian kredit dan investasi dana bank pada portofolio yang berbeda. Setiap penanaman dana bank dalam aset produktif, dinilai kualitasnya dengan menentukan tingkat kolektibilitasnya, yaitu apakah lancar/dalam perhatian khusus/kurang lancar/diragukan/macet. Pembedaan tingkat kolektibilitas tersebut diperlakukan untuk mengetahui besarnya cadangan minimum penghapusan aset produktif yang harus disediakan oleh bank untuk menutup risiko kemungkinan kerugian yang terjadi.

Rasio yang digunakan untuk mengukur asset quality adalah NPL (Non Performing Loan). Rasio ini menunjukan bahwa kemampuan manajemen bank dalam mengelola kredit bermasalah yang diberikan oleh bank. Sehingga semakin tinggi rasio ini maka akan semakin semakin buruk kualitas kredit bank yang menyebabkan jumlah kredit bermasalah semakin besar maka kemungkinan suatu bank dalam kondisi bermasalah semakin besar. Kredit dalam hal ini adalah kredit yang diberikan kepada pihak ketiga tidak termasuk kredit kepada bank lain. Kredit bermasalah adalah kredit dengan kualitas kurang lancar, diragukan dan macet.

\section{Management quality}

Menunjukkan kemampuan manajemen bank untuk mengidentifikasi, mengukur, mengawasi, dan mengontrol risiko-risiko yang timbul melalui kebijakan-kebijakan dan strategi bisnisnya untuk mencapai target. Manajemen suatu bank diwajibkan mengelola banknya dengan baik sesuai dengan peraturan di bidang perbankan yang berlaku agar bank tersebut sehat. Menurut Surat Edaran Bank Indonesia No.9/24/DPbS, penilaian faktor manajemen dipisahkan dengan penilaian faktor finansial, guna memberikan gambaran yang lebih utuh atas kondisi 
kevangan dan manajemen bank. Faktor manajemen dianggap sebagai leading indicator dalam penilaian sehingga tidak dapat dijadikan sebagai bagian dari penilaian faktor keuangan. Penilaian terhadap faktor manajemen dilakukan dengan menggunakan penilaian kualitatif untuk setiap aspek dari manajemen umum, manajemen risiko, dan manajemen kepatuhan.

\section{Earnings}

Menunjukkan tidak hanya jumlah kuantitas dan trend earning, tetapi juga faktor-faktor yang mempengaruhi ketersediaan dan kualitas earning. Penilaian didasarkan pada rentabilitas suatu bank yang dilihat dari kemampuan suatu bank dalam menciptakan laba. Rasio yang digunakan untuk mengukur earning adalah BOPO (Biaya Operasional terhadap Pendapatan Operasional). Rasio yang sering disebut rasio efisiensi ini digunakan untuk mengukur kemampuan manajemen bank dalam mengendalikan biaya operasional terhadap pendapatan operasional. Semakin kecil rasio ini berarti semakin efisien biaya operasional yang dikeluarkan bank yang bersangkutan sehingga kemungkinan suatu bank dalam kondisi bermasalah semakin kecil. Biaya operasional dihitung berdasarkan penjumlahan dari totall beban bunga dan total beban operasional lainnya. Pendapatan operasional adalah penjumlahan dari total pendapatan bunga dan total pendapatan operasional lainnya.

\section{Liquidity}

Yaitu untuk menilai likuiditas bank untuk menunjukkan ketersediaan dana dan sumber dana bank pada saat ini dan pada masa yang akan datang. Pengaturan likuiditas bank terutama dimaksudkan agar bank setiap saat dapat memenuhi kewajiban-kewajiban yang harus segera dibayar. Rasio yang digunakan untuk mengukur liquidity adalah LDR (Loan to Deposit Ratio). Rasio ini digunakan untuk menilai likuiditas suatu bank yang dengan cara membagi jumlah kredit yang diberikan oleh bank terhadap dana pihak ketiga. Semakin tinggi rasio ini, semakin rendahnya kemampuan likuiditas bank yang bersangkutan sehingga kemungkinan suatu bank dalam kondisi bermasalah akan semakin besar. Kredit yang diberikan tidak termasuk kredit kepada bank lain sedangkan untuk dana pihak ketiga adalah giro, tabungan, simpanan berjangka, sertifikat deposito.

\section{Size}

Size merupakan ukuran bank. Mishkin (2004; p.263) mengatakan bahwa bank besar memiliki kemungkinan kecil untuk bangkrut, karena adanya asumsi "too big to fail". Bank besar tidak akan dibiarkan bangkrut oleh pemerintah dikarenakan kebangkrutan bank besar akan mengindikasikan adanya kekacavan keuangan. Swandari (2006; p.62) dalam Kartika (2007) menyatakan bahwa semakin besar sebuah bank maka semakin besar pula kemampuannya untuk mendiversifikasi risiko sehingga memiliki kemungkinan kecil untuk mengalami kesulitan keuangan. Tetapi untuk Indonesia, data empiris menunjukkan bahwa banyak bank besar yang justru mengalami kesulitan keuangan di awal krisis. Ukuran bank dihitung dengan logaritma natural dari total kekayaan bank.

\section{Pengaruh CAR Terhadap Rating Obligasi}

Dari jurnal Almilia (2005), dapat diketahui bahwa rasio CAR mempunyai pengaruh negatif artinya semakin rendah rasio ini maka semakin besar kemungkinan suatu bank dalam kondisi bermasalah. Pengaruh rasio CAR terhadap kondisi bermasalah adalah signifikan karena tingkat signifikansi di bawah 0.05 yaitu sebesar 0.027. Jika semakin besar kemungkinan suatu bank dalam kondisi bermasalah, maka rating obligasinya turun. Maka, CAR berpengaruh positif terhadap rating obligasi bank.

\section{$\mathrm{H}_{1}$ : CAR mempengaruhi rating obligasi bank secara positif}

\section{Pengaruh NPL Terhadap Rating Obligasi}

Almilia (2005) mengatakan bahwa semakin tinggi rasio NPL maka akan semakin semakin buruk kualitas kredit bank yang menyebabkan jumlah kredit bermasalah semakin besar 
maka kemungkinan suatu bank dalam kondisi bermasalah semakin besar. Jika semakin besar kemungkinan suatu bank dalam kondisi bermasalah, maka rating obligasinya turun. Maka, NPL berpengaruh negatif terhadap rating obligasi bank.

\section{$\mathrm{H}_{2}$ : Diduga NPL mempengaruhi rating obligasi bank secara negatif}

\section{Pengaruh BOPO Terhadap Rating Obligasi}

Menurut jurnal Almilia (2005), semakin kecil rasio BOPO berarti semakin efisien biaya operasional yang dikeluarkan bank yang bersangkutan. Rasio BOPO mempunyai pengaruh positif artinya semakin tinggi rasio ini maka kemungkinan suatu bank dalam kondisi bermasalah semakin besar. Pengaruhnya terhadap kondisi bermasalah adalah signifikan karena tingkat signifikansinya dibawah 0.05 yaitu sebesar 0.019. Jika semakin besar kemungkinan suatu bank dalam kondisi bermasalah, maka rating obligasinya turun. Maka, BOPO berpengaruh negatif terhadap rating obligasi bank.

\section{$\mathrm{H}_{3}$ : Diduga BOPO mempengaruhi rating obligasi bank secara negatif}

\section{Pengaruh LDR Terhadap Rating Obligasi}

Almilia (2005) mengatakan bahwa semakin tinggi rasio LDR, semakin rendahnya kemampuan likuiditas bank yang bersangkutan sehingga kemungkinan suatu bank dalam kondisi bermasalah akan semakin besar. Jika semakin besar kemungkinan suatu bank dalam kondisi bermasalah, maka rating obligasinya turun. Maka, LDR berpengaruh negatif terhadap rating obligasi bank.

\section{$\mathrm{H}_{4}$ : Diduga LDR mempengaruhi rating obligasi bank secara negatif}

\section{METODE PENELITIAN}

\section{Jenis Penelitian dan Defenisi Operasional}

Jenis penelitian ini merupakan penelitian kausal. Penelitian ini menggunakan variabel terikat (dependent variable) dan variabel bebas (independent variable). Variabel terikat yaitu rating obligasi (RATE) diukur dengan 4 nilai, yaitu nilai 1-4. Nilai 1 (satu) akan diberikan jika rating obligasi suatu bank adalah BBB, nilai 2 (dua) akan diberikan jika rating obligasi suatu bank adalah A, nilai 3 (tiga) akan diberikan jika rating obligasi suatu bank adalah AA, dan nilai 4 (empat) akan diberikan jika rating obligasi suatu bank adalah AAA.

Sedangkan variabel bebasnya yaitu kinerja keuangan perbankan yang diukur dengan metode CAMEL. Capital adequacy diukur dengan menggunakan rasio CAR, yaitu rasio yang memperlihatkan seberapa besar jumlah seluruh aset bank yang mengandung risiko (kredit, penyertaan, surat berharga, tagihan pada bank lain) ikut dibiayai dari modal sendiri disamping memperoleh dana-dana dari sumber di luar bank, yaitu dengan cara membandingkan modal bank terhadap aset tertimbang menurut risiko (ATMR) pada bank.

Untuk asset quality menggunakan rasio NPL, yang didapat dari kemampuan manajemen bank dalam mengelola kredit bermasalah terhadap total kredit bank. Sedangkan management quality, menunjukkan kemampuan manajemen bank untuk mengidentifikasi, mengukur, mengawasi, dan mengontrol risiko-risiko yang timbul melalui kebijakan-kebijakan dan strategi bisnisnya untuk mencapai target. Manajemen suatu bank diwajibkan mengelola banknya dengan baik sesuai dengan peraturan di bidang perbankan yang berlaku agar bank tersebut sehat. Menurut Surat Edaran Bank Indonesia No.9/24/DPbS, penilaian faktor manajemen dipisahkan dengan penilaian faktor finansial, guna memberikan gambaran yang lebih utuh atas kondisi keuangan dan manajemen bank. Faktor manajemen dianggap sebagai leading indicator dalam penilaian sehingga tidak dapat dijadikan sebagai bagian dari penilaian faktor keuangan. Penilaian terhadap faktor manajemen dilakukan dengan 
menggunakan penilaian kualitatif untuk setiap aspek dari manajemen umum, manajemen risiko, dan manajemen kepatuhan.

Untuk earning diukur menggunakan rasio BOPO untuk mengukur kemampuan manajemen bank dalam mengendalikan biaya operasional terhadap pendapatan operasional pada bank. Sedangkan liquidity menggunakan rasio LDR, dengan cara membagi jumlah kredit yang diberikan oleh bank terhadap dana pihak ketiga pada bank.

LOGSIZE merupakan variabel ukuran bank di Indonesia periode 2005-2009 yang dihitung dari logaritma total aset. Variabel LOGSIZE disini berfungsi sebagai variabel kontrol. Variabel kontrol adalah variabel untuk melengkapi atau mengkontrol hubungan kausalnya supaya lebih baik untuk didapatkan model empiris yang lebih lengkap dan lebih baik (Jogiyanto, 2004; p.157). Digunakan variabel LOGSIZE untuk melihat fluktuasi kebangkrutan bank dari total aset yang dimiliki oleh bank.

\section{Jenis dan Sumber Data}

Data yang digunakan dalam penelitian ini adalah: data sekunder yang diperoleh dari Direktori Perbankan Indonesia tahun 2005-2009 yang terdapat di perpustakaan Bank Indonesia yang berupa laporan keuangan bank, data sekunder berupa rating obligasi sektor perbankan dan lembaga keuangan lainnya di Indonesia periode 2005-2009 yang didapat dari www.pefindo.com (website resmi Pefindo), dan data lain yang mendukung penelitian ini diperoleh dari literatur, jurnal ilmiah, dan download dari internet.

\section{Target dan Karakteritik Populasi}

Target populasi untuk penelitian ini adalah seluruh bank yang ada di Indonesia pada tahun 2005 sampai dengan tahun 2009. Sedangkan untuk karakteristik populasi yang diteliti adalah bank memiliki laporan keuangan lengkap berupa neraca dan laporan laba rugi yang tercatat lengkap di Direktori Perbankan Indonesia selama periode 2005-2009. Bank yang telah menerbitkan obligasi dan di-rating secara rutin oleh Pefindo selama periode 2005-2009. Berdasarkan hal tersebut, terdapat 19 bank yang memenuhi syarat untuk dianalisis lebih lanjut (Lampiran 1).

\section{Prosedur Pengumpulan Data}

Prosedur pengumpulan data dalam penelitian ini dimulai dengan mencari rating obligasi seluruh bank di Indonesia yang telah di-rating oleh Pefindo selama periode 2003-2011 yang didapat dari website resmi Pefindo. Dari ratusan bank di Indonesia, hanya 27 bank yang dirating oleh Pefindo pada kurun waktu tersebut. Dan dari 27 bank tersebut, hanya 19 bank saja yang memenuhi karakteristik populasi. Langkah selanjutnya adalah mendokumentasikan rasio-rasio keuangan dari 19 bank yang memenuhi karakteristik populasi tersebut. Data ini didapatkan dari Direktori Perbankan Indonesia tahun 2005-2009. Penggunaan kurun waktu 5 periode dikarenakan kurun waktu tersebut dirasa cukup panjang untuk mencerminkan trend kinerja keuangan bank.

\section{Metode Pengolahan Data}

Terdapat beberapa tahap yang harus dilalui untuk mengolah data mentah menjadi data yang dapat digunakan untuk penelitian, yaitu:

1. Memilih data yang akan digunakan untuk penelitian. Data yang telah dipilih (sesuai dengan karakteristik populasi yang telah ditentukan) dimasukkan kedalam Microsoft Excell 2007. Pertama-tama, menginputkan data rating obligasi 27 bank selama periode 2005-2009 yang didapat dari website Pefindo. 27 bank tersebut kemudian disortir menjadi 19 bank supaya sesuai dengan karakteristik populasi. Selanjutnya menginputkan rasio-rasio CAMEL per periode untuk ke-19 bank tersebut selama periode 2005-2009 sesuai dengan data yang didapat dari Direktori Perbankan Indonesia. Langkah berikutnya adalah mengubah variabel dependen berupa data rating obligasi (RATE) yang telah didapatkan menjadi nilai 1 sampai dengan 4. Nilai 1 mewakili rating BBB, nilai 2 mewakili rating A, nilai 3 mewakili rating AA, dan nilai 4 untuk mewakili rating 
AAA. Digunakan hanya 4 nilai karena rating terendah untuk 19 bank yang telah dipilih selama periode 2005-2009 yang didapat adalah BBB dan rating tertingginya adalah AAA.

2. Membuat statistik deskriptif dari data yang ada. Statistik deskriptif merupakan proses transformasi data penelitian dalam bentuk tabulasi sehingga mudah dipahami dan diinterpretasikan. Hal ini dilakukan dengan cara menghitung mean, deviasi standar, varians, median, batas bawah (min), dan batas atas (max) untuk variabel CAMEL yang dilihat dari rasio-rasionya dan variabel Logsize. Semua perhitungan statistik deskriptif ini dilakukan dengan menggunakan fungsi formula yang ada pada Microsoft Excell 2007.

3. Melakukan pengujian terhadap data bank, yaitu dengan menggunakan program komputer Eviews 4.1. Motode yang digunakan adalah Ordered Probit. Dalam statistika, model probit adalah jenis regresi dimana variabel terikatnya hanya memiliki dua nilai. Sedangkan ordered probit adalah generalisasi dari metode analisa probit untuk dua atau lebih outcome dari variabel terikat yang bersifat ordinal (http://en.wikipedia.org/wiki/Ordered probit). Metode ini dipilih karena variabel terikat yang digunakan adalah variabel ordinal multinominal yang berurutan (ordered data).

\section{Rancangan Uji Hipotesis}

Uji hipotesis dimaksudkan untuk mengetahui kebenaran dari suatu hipotesis. Tujuannya adalah untuk menganalisis dan menarik kesimpulan terhadap masalah yang akan diteliti. Dalam bagian ini ditentukan null hypothesis $\left(H_{0}\right)$ dan alternative hypothesis $\left(H_{1}\right)$ untuk masing-masing hipotesis yang ada. Model persamaan untuk penelitian ini adalah :

$$
Y=R A T E=a+\beta_{1}(C A R)+\beta_{2}(N P L)+\beta_{3}(B O P O)+\beta_{4}(L D R)+e
$$

Hipotesis pertama:

$H_{0}: \beta_{1} \leq 0$, Diduga CAR tidak mempengaruhi rating obligasi bank

$H_{1}: \beta_{1}>0$, Diduga CAR mempengaruhi rating obligasi bank secara positif

Hipotesis kedua:

$H_{\circ}: \beta_{1} \geq 0$, Diduga NPL tidak mempengaruhi rating obligasi bank

$H_{1}: \beta_{1}<0$, Diduga NPL mempengaruhi rating obligasi bank secara negatif

Hipotesis ketiga:

$H_{\circ}: \beta_{1} \geq 0$, Diduga BOPO tidak mempengaruhi rating obligasi bank

$\mathrm{H}_{1}: \beta_{1}<0$, Diduga BOPO mempengaruhi rating obligasi bank secara negatif

Hipotesis keempat:

$H_{0}: \beta_{1} \geq 0$, Diduga LDR tidak mempengaruhi rating obligasi bank

$H_{1}: \beta_{1}<0$, Diduga LDR mempengaruhi rating obligasi bank secara negatif

\section{HASIL DAN DISKUSI}

\section{Hasil}

Untuk mengetahui pengaruh CAMEL dan LOGSIZE terhadap rating obligasi, dilakukan pengujian dengan menggunakan uji regresi ordered probit dengan QML (Huber/White) Standart Error \& Covariance. Agar model ordered probit dapat diterapkan dengan acuan theoritical relevance maupun logical relevance, maka perlu di tinjau masalah multikolinieritas, otokorelasi dan heteroskedasitas. Untuk masalah multikolinieritas, penelitian ini tidak mengalami masalah, sebagaimana software Eviews 4.1 yang digunakan akan secara otomatis menunjukkan layar dengan sinyal kesalahan (error message) "Near Singular Matrix" apabila variabel-variabel independen yang dimasukkan ke dalam model mengalami problem multikolinieritas. Karenanya proses data akan terhenti secara otomatis (Eviews 4 User's Guide, 2002: 276).

Software ini juga menyediakan fasilitas yang akan mendeteksi adanya otokorelasi yaitu correlogram. Apabila gambar indikator otokorelasi tidak melewati garis batas patah-patah (standar error bound $\pm 2 / \sqrt{ } \mathrm{T}$ ) maka berarti tidak terjadi otokorelasi. Dari grafik otokorelasi pada Lampiran 2, terlihat hampir rata-rata semua tidak berada diluar batas tersebut, sehingga diindikasikan model probit bertingkat ini tidak mengalami otokorelasi. Masalah heterokedasitas dalam software Eviews 4.1 telah menghitung residual model probit 
bertingkat ini dengan metode generalized residual dimana residual ini dapat didefinisikan sebagai residual yang tidak berkorelasi dengan variabel independen di dalam model (Eviews 4 User's Guide, 2002:444) sehingga masalah heterokedasitas bisa diabaikan.

Hasil pengujian dapat dilihat pada Lampiran 3. Dari hasil pengujian tersebut, dapat dilihat bahwa rasio CAR yang memproksikan capital adequacy bernilai positif dan signifikan, hal ini berarti $\mathrm{H}_{1}$ diterima. Rasio NPL yang memproksikan asset quality bernilai negatif dan signifikan, hal ini berarti $\mathrm{H}_{1}$ diterima. Rasio BOPO yang memproksikan earning bernilai positif dan signifikan, hal ini berarti $\mathrm{H}_{1}$ ditolak. Rasio LDR yang memproksikan liquidity bernilai positif dan signifikan, hal ini berarti $\mathrm{H}_{1}$ ditolak. Variabel LOGSIZE bernilai positif dan signifikan. Hasil pengujian ordered probit ini menghasilkan LR index (Pseudo-R2) sebesar 0,531627. Melalui hasil pengujian Ordered Probit tersebut, didapat model persamaan:

RATE = 0,095 CAR* - 0,296 NPL* + 0,047 BOPO** + 0,042 LDR* +e

Keterangan:

$*=$ Signifikan pada $a=1 \%$

$* *=$ Signifikan pada $a=5 \%$

Hasil pengujian ordered probit ini menghasilkan LR index (Pseudo-R2) sebesar 0,533236. Hasil ini menunjukkan bahwa variabel-variabel independen yang digunakan dalam penelitian ini cukup dapat menjelaskan variabel dependennya sebesar $53,16 \%$. Sisa sebesar $46,84 \%$ dijelaskan oleh variabel lain diluar model.

\section{Diskusi}

Berdasarkan statistik deskriptif (Lampiran 4) tampak bahwa Rasio CAR mengalami penurunan pada tahun 2008 yang tidak lain disebabkan karena adanya penyaluran kredit yang cukup ekspansif oleh bank-bank di Indonesia. Di tengah-tengah krisis ekonomi dunia, pertumbuhan kredit perbankan nasional meningkat pesat. Sampai dengan Desember 2008 kredit tumbuh mencapai 30,7 persen dengan nilai Rp1.300,2 triliun, jauh lebih tinggi dibandingkan pertumbuhan tahunan 2007 yang sebesar 26,4 persen (www.bappenas.go.id/get-fileserver/node/7621/).

Pertumbuhan kredit tertinggi terjadi pada sektor listrik, sementara itu kredit ke sektor pertambangan dan pertanian mengalami pelambatan terpengaruh oleh perkembangan harga internasional. Pertumbuhan kredit tertinggi pada sektor listrik, diikuti kemudian oleh sektor pengangkutan dan telekomunikasi, jasa dunia usaha, dan konstruksi. Hal ini juga terkait dengan upaya Pemerintah dalam memenuhi kebutuhan energi listrik yang meningkat. Sementara itu, sektor pertambangan, jasa sosial, pertanian, dan perdagangan tumbuh lebih rendah dibandingkan dengan pertumbuhan yang dicapai tahun 2007. Khusus untuk kredit sektor pertambangan dan pertanian sebenarnya sempat tumbuh tinggi meski kemudian melambat sejalan dengan perkembangan harga komoditas internasional. Walaupun mengalami penurunan, rasio CAR bank yang rata-rata masih berada di angka 16,2405 (16\%) masih dikatakan berada pada titik aman karena jauh dari batas minimal yang ditetapkan oleh $\mathrm{BI}$, yaitu $8 \%$. Jika dibawah $8 \%$, maka bank dinyatakan tidak sehat.

Rasio CAR yang memproksikan capital adequacy bernilai positif dan signifikan konsisten dengan penelitian yang dilakukan oleh Thomson (1991) dan Almilia (2005) yang membuktikkan bahwa terdapat hubungan negatif antara capital adequacy dengan kebangkrutan bank. Hubungan antara kebangkrutan dan rating obligasi bersifat negatif; semakin tinggi risiko kebangkrutan, maka semakin rendah rating obligasi, begitu pula sebaliknya. Karena itu, secara tidak langsung, jurnal Thomson (1991) juga mengatakan bahwa capital adequacy berpengaruh positif terhadap rating obligasi.

Penurunan NPL merupakan bukti dari kuatnya sektor perbankan Indonesia dalam menghadapi krisis global. Kualitas kredit tetap terpelihara baik, sebagaimana tercermin 
pada Non Performing Loan (NPL) tahun 2008, baik gross maupun net, yang berhasil mencatat angka terendah semenjak krisis keuangan Asia tahun 1997/1998 dan sekaligus berada jauh di bawah target indikatif yang ditetapkan Bank Indonesia. Puncak tertinggi BOPO yang terjadi pada tahun 2008 disebabkan oleh kondisi profitabilitas yang sempat tertekan pada pertengahan tahun akibat kenaikan suku bunga dan jatuhnya harga SUN, namun tertolong oleh kebijakan BI dan Dewan Standar Akuntasi Keuangan-IAl yang memungkinkan fleksibilitas dalam pencatatan SUN.

Rasio NPL yang memproksikan asset quality bernilai negatif dan signifikan. Hasil ini konsisten dengan jurnal Almilia (2005) yang mengatakan bahwa semakin tinggi rasio ini (NPL) maka akan semakin semakin buruk kualitas kredit bank yang menyebabkan jumlah kredit bermasalah semakin besar maka kemungkinan suatu bank dalam kondisi bermasalah semakin besar. Jika mengikuti pernyataan Almilia tersebut, dapat disimpulkan bahwa kualitas aset yang diproksikan dengan menggunakan rasio NPL berpengaruh negatif terhadap rating obligasi.

Rasio LDR yang tinggi pada tahun 2008 dan 2009 disebabkan oleh ketidakseimbangan pertumbuhan kredit dan pertumbuhan dana pihak ketiga (DPK). Pertumbuhan kredit yang tinggi ternyata disertai oleh pertumbuhan DPK yang lebih rendah, sehingga menimbulkan risiko likuiditas di beberapa bank, meskipun secara sistem likuiditas tetap mencukupi. Kecepatan pertumbuhan kredit sebesar $29,5 \%$ atau meningkat Rp308,0 triliun tidak diimbangi oleh laju peningkatan DPK yang tumbuh sebesar 16,1\% atau meningkat Rp242,6 triliun. Untuk memenuhi komitmen kreditnya, perbankan mencairkan SBI yang dimilikinya, sehingga komposisi SBI dalam aktiva produktif bank menurun. Kondisi ini membuat likuiditas perbankan berkurang. Dalam rangka membantu melonggarkan likuiditas bank umum ini, BI merespons dengan menurunkan kewajiban Giro Wajib Minimum (GWM) bank umum. Rendahnya pertumbuhan DPK dipengaruhi oleh strategi penggalangan dana murah perbankan. Pertumbuhan DPK yang melambat pada semester I-2008 antara lain dipengaruhi oleh penurunan suku bunga dan kebijakan beberapa bank besar pada awal tahun 2008 untuk mengurangi dana mahal berupa deposito dan melakukan pengalihan ke dana yang lebih murah (Laporan Perekonomian Indonesia Tahun 2008; Bab IV).

Rasio LDR yang memproksikan liquidity bernilai positif dan signifikan. Hal ini tidak konsisten dengan jurnal Thomson (1991) dan Almilia (2005) yang menyimpulkan bahwa liquidity berpengaruh positif dan signifikan terhadap kebangkrutan, atau dengan kata lain berpengaruh negatif signifikan terhadap rating obligasi. Menurut Almilia (2005), semakin tinggi rasio LDR, semakin rendah kemampuan likuiditas bank yang bersangkutan sehingga kemungkinan suatu bank dalam kondisi bermasalah akan semakin besar. Pada kenyataannya, terkait dengan konsep "high risk, high return", LDR tidak hanya berbicara mengenai risiko likuiditas namun juga pendapatan bank. LDR memiliki dua komponen, yaitu jumlah kredit yang diberikan bank (loan) dan dana pihak ketiga (deposit). Sumber pendapatan bank salah satunya berasal dari bunga pinjaman (loan) yang diberikan kepada masyarakat. Maka dapat dikatakan bahwa ada hubungan antara LDR dan profit suatu bank. Hal tersebut diilustrasikan melalui Gambar berikut ini: 


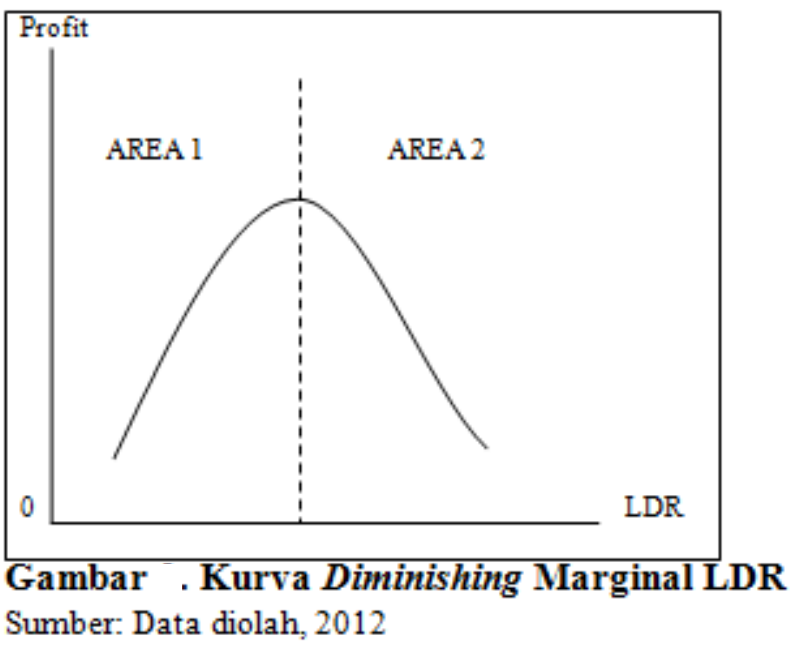

Gambar tersebut menunjukkan hubungan antara LDR dan profit bank. Pada area 1, terlihat ada hubungan positif antara LDR dan profit. Jika diimbangi dengan manajemen loan yang baik, semakin tinggi LDR maka pendapatan (profit) yang didapat dari loan semakin tinggi. Pada area 1 ini, peningkatan cost (risiko likuiditas) diimbangi dengan peningkatan benefit (profit). Namun pada satu titik, akan terjadi diminishing LDR. Peningkatan LDR akan berpengaruh negatif terhadap profit. Hal inilah yang terlihat pada area 2. Peningkatan cost (risiko likuiditas) menghasilkan penurunan benefit (profit).

Kesimpulannya, LDR tidak hanya berbicara mengenai risiko likuiditas, namun juga profit, yang menjadi salah satu faktor penilaian rating obligasi. Semakin tinggi profit, semakin tinggi rating obligasi. Maka dalam kasus tertentu, LDR berpengaruh positif terhadap rating obligasi. Karena hal itu pula Bank Indonesia memiliki target LDR ideal seperti yang disampaikan dalam Peraturan Bank Indonesia Nomor 12/19/PBI/2010. Batas bawah target LDR adalah $78 \%$ dan batas atasnya $100 \%$. Peningkatan LDR akan dianggap semakin meningkatkan kualitas bank jika sampai pada target LDR tersebut.

Rasio BOPO yang memproksikan earning bernilai positif dan signifikan. Hal ini tidak konsisten dengan jurnal Almilia (2005). Almilia (2005) mengatakan bahwa semakin kecil rasio BOPO berarti semakin efisien biaya operasional yang dikeluarkan bank yang bersangkutan sehingga kemungkinan suatu bank dalam kondisi bermasalah semakin kecil. Secara tidak langsung, Almilia (2005) mengatakan bahwa BOPO berpengaruh positif terhadap kebangkrutan dan berpengaruh negatif terhadap rating obligasi. Jika demikian, maka hasil dari penelitian ini berkebalikan dengan hasil penelitian Almilia (2005).

BOPO adalah rasio efisiensi yang digunakan untuk mengukur kemampuan manajemen bank dalam mengendalikan biaya operasional terhadap pendapatan operasional. Memang benar bahwa semakin tidak efisien, maka rating obligasi semakin rendah. Akan tetapi, pada kenyataannya, rasio BOPO tidak hanya berbicara mengenai efisiensi saja. Tingginya rasio BOPO pada kenyataanya tidak hanya memberi arti bahwa suatu bank berada dalam kondisi inefisiensi, seperti kata Gubernur Bank Indonesia, juga bisa berarti bahwa pinjaman kredit yang disalurkan kepada masyarakat rendah (http://economy.okezone.com/read/2011/12/09/457/ 540439/bopo-perbankan-indonesiatertinggi-di-asean). Pemberian pinjaman yang minim ini dapat meminimalkan risiko kredit. Risiko kredit terjadi jika counterparty (pihak lain dalam transaksi bisnis kita) tidak bisa memenuhi kewajibannya (wanprestasi). Semakin kecil pinjaman, maka semakin kecil risiko kredit. Jika risiko suatu bank semakin kecil, maka rating obligasinya semakin tinggi.

Kesimpulannya, jika dilihat dari segi efisiensi, maka earning yang diproksikan menggunakan rasio BOPO berpengaruh negatif terhadap rating obligasi. Namun apabila dilihat dari segi risiko kredit, maka BOPO berpengaruh positif terhadap rating obligasi. Jika BOPO kecil, maka 
Theofilus Steven Susanto

Bertha Silvia Sutejo

Deddy Marciano

dapat dikatakan bahwa suatu bank tersebut efisien namun pinjaman yang disalurkan tinggi sehingga risiko kreditnya tinggi, begitu pula sebaliknya. Oleh karena itu, untuk menyeimbangkan kedua hal tersebut, maka Deputi Gubernur Bank Indonesia menyampaikan bahwa kondisi ideal BOPO suatu bank adalah $60-70 \%$ (http://keuangan.kontan.co.id/news/bank-boros-harus-menekan-ongkos).

Untuk variabel LOGSIZE yang mencerminkan UkUran suatu bank, mengalami tren positif (meningkat dari tahun ke tahun) baik pada rata-rata, nilai tengah, batas bawah dan batas atas. Tren positif dari aset bank umum di Indonesia ini sekali lagi menunjukkan kuatnya sektor perbankan yang ada di Indonesia dan keberhasilan kebijakan perekonomian di Indonesia dalam mengantisipasi dan mengatasi dampak krisis global yang terjadi. Variabel LOGSIZE bernilai positif dan signifikan menunjukkan bahwa ukuran bank berpengaruh positif terhadap rating obligasi. Makin besar ukuran bank, maka kemungkinan bank tersebut untuk mendapat rating obligasi yang tinggi semakin besar karena dianggap bank tersebut memiliki risiko likuiditas yang kecil. Hal ini konsisten dengan asumsi "too big to fail" yang dikemukakan oleh Mishkin (2004; p.263). Hal ini dikarenakan bank yang memiliki ukuran besar memiliki sumber pendanaan yang lebih besar dibandingkan dengan perusahaan yang memiliki aset kecil. Hal ini berdampak pada makin tingginya kemampuan untuk menyalurkan dana dan memenuhi kewajibannya, sehingga kemungkinan bank mengalami kebangkrutan karena kekurangan dana dapat diminimalkan.

\section{SIMPULAN}

Dari hasil pengujian, dapat disimpulkan bahwa ada empat faktor yang berpengaruh seacara signifikan terhadap rating obligasi. Faktor tersebut adalah capital adequacy, asset quality, earning dan liquidity. CAR terbukti berpengaruh positif terhadap rating obligasi. Modal yang cukup berakibat pada bank tidak akan kekurangan dana dan bank dapat memenuhi kewajibannya sehingga risiko kebangkrutan dapat diperkecil. Semakin kecil risiko kebangkrutan, maka rating obligasi suatu bank semakin tinggi. Asset quality pada penelitian ini menunjukkan hasil yang konsisten dengan jurnal Almilia (2005) yang mengatakan bahwa NPL berpengaruh positif terhadap kebangkrutan, atau yang berarti berpengaruh negatif terhadap rating obligasi.

Earning yang diproksikan melalui BOPO pada penelitian ini menunjukkan hasil yang tidak konsisten dengan penelitian sebelumnya yang mengatakan bahwa BOPO berpengaruh positif terhadap kebangkrutan, atau yang berarti berpengaruh negatif terhadap rating obligasi. Dalam penelitian ini, BOPO berpengaruh positif terhadap rating obligasi. Hal ini disebabkan karena BOPO tidak hanya mencerminkan efisiensi saja. BOPO yang tinggi juga memberi arti bahwa suatu bank menyalurkan kredit kepada masyarakat dalam jumlah yang kecil. Jika demikian, maka risiko kreditnya juga kecil dan rating obligasinya naik. Karena itu, dalam kasus tertentu, jika dilihat dari sisi risiko, BOPO bisa saja berpengaruh positif terhadap rating obligasi.

Liquidity yang diproksikan menggunakan LDR juga menunjukkan hasil yang tidak konsisten dengan teori dan penelitian sebelumnya. Pada penelitian sebelumnya, LDR berpengaruh positif terhadap kebangkrutan atau yang berarti LDR berpengaruh negatif terhadap rating obligasi, sedangkan dalam penelitian ini, LDR berpengaruh positif terhadap rating obligasi. Perbedaan hasil penelitian ini disebabkan karena LDR tidak hanya berbicara tentang masalah risiko likuiditas, namun juga harus dipahami bahwa ada sisi profit didalam LDR. Dalam batas tertentu, LDR berpengaruh positif terhadap profit, yang berarti berpengaruh positif terhadap rating obligasi.

Pada penelitian ini juga digunakan satu variabel kontrol, yaitu variabel LOGSIZE yang merupakan cerminan dari ukuran bank. Makin besar ukuran bank, maka kemungkinan bank tersebut untuk mendapat rating obligasi yang tinggi semakin besar karena dianggap bank tersebut memiliki risiko likuiditas yang kecil. Hal ini sesuai dengan asumsi "too big to fail" yang 
dikemukakan oleh Mishkin (2004; p.263). Hal ini dikarenakan bank yang memiliki ukuran besar memiliki sumber pendanaan yang lebih besar dibandingkan dengan perusahaan yang memiliki aset kecil. Hal ini berdampak pada makin tingginya kemampuan untuk menyalurkan dana dan memenuhi kewajibannya, sehingga kemungkinan bank mengalami kebangkrutan karena kekurangan dana dapat diminimalkan.

Implikasi penelitian diharapkan dapat menjadi informasi bagi pihak manajemen bank. Dengan mengetahui pengaruh kinerja keuangan terhadap rating obligasi pada bank-bank di Indonesia, diharapkan kedepannya dapat menjadi pertimbangan bagi pihak manajemen bank dalam mengambil keputusan keuangan, sehingga dapat meningkatkan rating obligasi bank yang sedang dipimpinnya. Selain itu, penelitian ini juga dapat menjadi infomasi bagi para investor dan calon investor obligasi bank-bank di Indonesia. Dengan mengetahui hasil penelitian ini, para investor dapat memprediksi rating obligasi dari sebuah bank dengan mengamati laporan keuangannya.

Dalam mengamati laporan keuangan bank, diperlukan suatu penilaian tentang kinerja keuangan bank. CAMEL merupakan salah satu metode yang dapat digunakan untuk menilai kinerja keuangan suatu bank. Penelitian ini membuktikan bahwa capital adequcy, asset quality, earning, liquidity, dan ukuran perusahaan berpengaruh secara signifikan terhadap rating obligasi bank di Indonesia periode 2005-2009. Sedangkan penilaian management quality oleh Bank Indonesia dilakukan dengan menggunakan penilaian kualitatif, bukan kuantitatif.

Penelitian ini juga memberikan beberapa rekomendasi sebagai berikut:

1. Bagi Bank Indonesia selaku bank sentral dan pengawas bank-bank yang ada di Indonesia, diharapkan hasil penelitian ini dapat menjadi pertimbangan-pertimbangan tertentu dalam perumusan atau perbaikan kebijakan dan peraturan oleh bank Indonesia mengenai penilaian kinerja keuangan bank di Indonesia supaya rating obligasi bankbank di Indonesia bisa semakin baik dan investor domestik maupun asing semakin tertarik berinvestasi pada obligasi sektor perbankan dan keuangan di Indonesia.

2. Bagi pihak manajemen bank, diharapkan hasil penelitian ini dapat dijadikan sebagai panduan dalam hal menilai kinerja keuangan bank dan dapat dijadikan sebagai sarana evaluasi sehingga mengetahui letak kekurangan dan kelemahan yang dihadapi oleh bank yang sedang dipimpinnya. Selain itu, diharapkan pihak manajemen dapat mengambil tindakan korektif apabila rating obligasi bank yang dipimpinnya sedang mengalami kondisi stagnan atau menurun. Dengan demikian, rating obligasi bank-bank di Indonesia dapat meningkat dan menarik perhatian investor domestik dan asing.

3. Bagi investor dan calon investor, diharapkan penelitian ini dapat menjadi suatu panduan untuk memprediksi rating obligasi dari sebuah bank dengan mengamati laporan keuangannya.

4. Bagi peneliti di bidang keuangan, diharapkan penelitian ini dapat menjadi bahan referensi untuk melakukan penelitian selanjutnya, misalnya penelitian dengan menggunakan metode penilaian yang berbeda atau penelitian dengan menambahkan variabel independen, contohnya seperti rasio-rasio lain yang digunakan oleh Almilia (2005) yaitu ATTM, APB, PPAP, PPAPAP, ROA, ROE, dan lain-lain atau variabel kontrol lainnya, contohnya period (kondisi krisis - non krisis). Penelitian ini juga memiliki kelemahan karena tidak menggunakan proxy apapun untuk mengukur manajement quality. Dengan melakukan penelitian-penelitian lebih lanjut tersebut, diharapkan semakin dapat diketahui apakah faktor-faktor penting lainnya yang dapat mempengaruhi rating obligasi bank di Indonesia.

\section{Referensi}

Arena, Marco, 2005, Bank Failures And Bank Fundamentals: A Comparative Analysis of Latin America And East Asia During The Nineties Using Bank-Level Data, Bank of Canada Working Paper. 
Theofilus Steven Susanto

Bertha Silvia Sutejo

Deddy Marciano

Budipratama, Severino, 2010, Pefindo's Corporate Default And Rating Transition Study (19962010), http://new.pefindo.com/files/2010_defaultstudy.pdf

Cahyo, 2012, Obligasi Korporasi RI Makin Menarik, http:// www.neraca.co.id/2012/05/09/obligasi-korporasi-ri-makin-menarik/.

Djarwanto, 1996, Mengenal Beberapa Uji Statistik Dalam Penelitian, Liberty.

Fauzi, Muhhamad, 2010, Bab 5: Analisis dan Pembahasan, http://lontar.ui.ac.id/file? file=digital/135536-T\%2027968-Faktor-faktor\%20yangAnalisis.pdf.

Franedya, Roy, 2012, Bank Boros Harus Menekan Ongkos, http:// keuangan.kontan.co.id/news/bank-boros-harus-menekan-ongkos

Hadad, Muliaman, Wimboh Santoso dan Srawedi, 2004, Model Prediksi Kepailitan Bank Umum di Indonesia, Research Paper Direktorat Penelitian Dan Pengaturan Perbankan, Bank Indonesia.

Hanafi, Mamduh M., 2009, Manajemen Risiko, Edisi Kedua, UPP STIM KYPN.

Hubbard, R. Glenn, 2005, Money, The Financial System, And The Economy, $5^{\text {th }}$ Edition, Pearson Education.

Jogiyanto, H. M., 2004, Metodologi Penelitian Bisnis: Salah Kaprah dan PengalamanPengalaman, BPFE-Yogyakarta.

Jurusan Manajemen FBE Ubaya, 2009, Pedoman Penulisan Skripsi Jurusan Manajemen, Fakultas Bisnis dan Ekonomika, Fakultas Bisnis dan Ekonomika, Universitas Surabaya.

Kartika, Margaretha, 2007, Pengaruh Kesehatan Bank Terhadap Kebangkrutan Bank Di Indonesia Periode 1998-2005, Universitas Surabaya.

LSY, 2012, Kenapa Perusahaan Menerbitkan Obligasi, http:// sjconsulting.web.id/?p=176

Maftuhah, Gina N., 2011, BOPO Perbankan Indonesia Tertinggi Di ASEAN, http://economy.okezone.com/read/2011/12/09/457/540439/bopo-perbankanindonesia-tertinggi-di-asean

Martono, 2004, Bank dan Lembaga Kevangan Lainnya, Cetakan Ketiga, Edisi Pertama, Ekonisia.

Mishkin, Frederic, 2004, The Economic Of Money, Banking, and Financial Market, Seventh Edition, Pearson International.

Salim, Agus, 2012, Pasar Obligasi 2012 Akan Atraktif, http://www.cimb-principal.co.id/News@-Pasar_Obligasi_2012_Akan_Atraktif.aspx.

Siamat, Dahlan, 1999, Manajemen Lembaga Keuangan, Fakultas Ekonomi Universitas Indonesia.

Siregar, Silvia, 2011, Pengaruh Pertumbuhan Hutang dan Asimetri Informasi Terhadap Penilaian Pasar Atas Discretionary Accrual,

http://jurnalilmiahmanajemen.files.wordpress.com/2011/03/pengaruh-pertumbuhanhutang-dan-asimetri-informasi.pdf.

Spica, Luciana Almilia dan Winny Herdiningtyas, 2005, Analisis Rasio CAMEL Terhadap Prediksi Kondisi Bermasalah Pada Lembaga Perbankan Perioda 2000-2002, Jurnal Akuntansi Dan Keuangan, Volume 7.

Suharli, Michell, 2008, Pengaruh Rasio Keuangan dan Konservatisme Akuntansi Terhadap Pemeringkatan Obligasi, Universitas Katholik Indonesia Atmaja Jakarta.

Susilo, Sri, Sigit Triandaru dan A. Totok Budi Santoso, 2009, Bank dan Lembaga Keuangan Lainnya, Cetakan Pertama, Salemba Empat.

Tandelilin, Eduardus, 2010, Portofolio dan Investasi: Teori dan Aplikasi, Kanisius.

Taswan, 2006, Manajemen Perbankan; Konsep, Teknik, Dan Aplikasi, Cetakan Pertama, UPP STIM YKPN.

Thomson, James B., 1991, Predicting Bank Failures in the 1980s, Economic Review-Federal Reserve Bank of Cleveland.

Tim Informasi Hukum, Direktorat Hukum, 2010, Peraturan Bank Indonesia Nomor 12/19/PBI/2010-Giro Wajib Minimum Bank Umum pada Bank Indonesia dalam Rupiah dan Valuta Asing, http://www.bi.go.id/web/id/Peraturan/Perbankan/pbi_121910.htm 
Tim Informasi Hukum, Direktorat Hukum, 2007, Surat Edaran Bank Indonesia No. 9/24/DPbS Sistem Penilaian Tingkat Kesehatan bank Umum Berdasarkan Prinsip Syariah, http://www.bi.go.id/ web/id/Peraturan/Perbankan/se_092407.htm

Wikipedia, 2012, Ordered Probit, http://en.wikipedia.org/wiki/ Ordered probit.

Wilopo, 2001, Prediksi Kebangkrutan Bank, Jurnal Riset Akuntansi Indonesia, Volume 4. 2008, Buku Laporan Perekonomian Indonesia 2008, Bank Indonesia 2009, Buku Pegangan 2009, www.bappenas.go.id/get-file-server/ node/7621/ 2005, Direktori Perbankan Indonesia Tahun 2005, Urusan Pengaturan dan Pengembangan Perbankan, Bank Indonesia.

2006, Direktori Perbankan Indonesia Tahun 2006, Urusan Pengaturan dan Pengembangan Perbankan, Bank Indonesia.

2007, Direktori Perbankan Indonesia Tahun 2007, Urusan Pengaturan dan Pengembangan Perbankan, Bank Indonesia.

2008, Direktori Perbankan Indonesia Tahun 2008, Urusan Pengaturan dan Pengembangan Perbankan, Bank Indonesia.

, 2009, Direktori Perbankan Indonesia Tahun 2009, Urusan Pengaturan dan Pengembangan Perbankan, Bank Indonesia. 2002, EViews 4 User's Guide, Quantitative Micro Software.

2012, Investment Grade Rating Indonesia Memberikan Dampak Positif Terhadap Prospek Obligasi Indonesia 2012, http:// vibiznews.com/column/bondsmutual.

Data-Data Pefindo, www.pefindo.com 
Theofilus Steven Susanto

Bertha Silvia Sutejo

Deddy Marciano

\section{Lampiran}

Lampiran 1

\section{Hasil Statistik Inferensial}

Dependent Variable: RATE

Method: ML - Ordered Probit (Quadratic hill climbing)

Date: 09/14/12 Time: 17:10

Sample: 195

Included observations: 95

Number of ordered indicator values: 4

Convergence achieved after 6 iterations

QML (Huber/White) standard errors \& covariance

\begin{tabular}{crrrr}
\hline \hline & Coefficien & Std. Error & z-Statistic & Prob. \\
& & & & \\
\hline \hline CAR* & 0.094942 & 0.029953 & 3.169693 & 0.0015 \\
NPL* & -0.296059 & 0.069352 & -4.268933 & 0.0000 \\
BOPO** & 0.046811 & 0.021034 & 2.225542 & 0.0260 \\
LDR* & 0.041696 & 0.010703 & 3.895637 & 0.0001 \\
LOGSIZE* & 3.794150 & 0.516181 & 7.350426 & 0.0000 \\
\hline \hline \multicolumn{5}{c}{ Limit Points } \\
\hline \hline LIMIT_2:C(6) & 34.67664 & 5.194530 & 6.675607 & 0.0000 \\
LIMIT_3:C(7) & 38.25752 & 5.558160 & 6.883126 & 0.0000 \\
LIMIT_4:C(8) & 40.59584 & 5.674284 & 7.154354 & 0.0000 \\
\hline \hline Akaike info criterion & 1.215726 & Schwarz criterion & 1.430789 \\
Log likelihood & -49.74697 & Hannan-Quinn criter. & 1.302627 \\
Restr. log likelihood & -106.2123 & Avg. log likelihood & -0.523652 \\
LR statistic (5 df) & 112.9306 & LR index (Pseudo-R2) & 0.531627 \\
Probability(LR stat) & 0.000000 & & & \\
\hline \hline
\end{tabular}

Sumber : Data diolah, 2012

\section{Keterangan:}

*=Signifikan pada $a=1 \%$

$* *=$ Signifikan pada $a=5 \%$ 